\title{
References
}

Dawes, P. R. 1966: Lower Palaeozoic geology of the western part of the North Greenland Fold Belt. Rapp. Gronlands geol. Unders. 11, 11-15.

Ellitsgaard-Rasmussen, K. 1955: Features of the geology of the folding range of Peary Land North Greenland. Meddr Gronland 127, 7.

Fränkl, E. 1955: Rapport über die Durchquerung von Nord Peary Land (Nordgrönland) im Sommer 1953. Meddr Gronland 103, 8.

Koch, L. 1920: Stratigraphy of Northwest Greenland. Meddr dansk geol. Foren. 5, 17, 1-78.

Koch, L. 1923a: Resultaterne af Jubilæumsekspeditionen Nord om Grønland i 1921. Naturens Verden 7 , 49-76.

Koch, L. 1923b: Preliminary report upon the geology of Peary Land, Arctic Greenland. Am. J. Sci., 5th Ser. 5, 189-199.

Koch, L. 1925: Geology of North Greenland. Am. J. Sci., 5th Ser. 9, 271-285.

Troelsen, J. C. 1956: The Cambrian of North Greenland and Ellesmere Island. 20 Congr. geol. intern. México, 1956. Symp. 3. 1. 71-90.

\section{QUATERNARY STUDIES IN NORTHERN PEARY LAND}

\section{Peter R. Dawes}

In connection with the bedrock investigations reported in the previous article, some time was spent on Quaternary studies. Pelecypods for radiocarbon dating were collected from marine clay and silt at the head of O. B. Bøggild Fjord, in Nordpasset, at the head of Frigg Fjord and in Citronens Fjord on the south coast of Frederick E. Hyde Fjord. The highest level of marine sediments, over $60 \mathrm{~m}$, was noted in Nordpasset. Driftwood from raised beaches of different heights was collected on the south side of Frederick E. Hyde Fjord for possible age dating, and the heights of marine terraces were measured by hand-level at $\mathrm{O}$. B. Bøggild Fjord, at the head of Frederick E. Hyde Fjord and at the head of Citronens Fjord.

Along the north coast between Kap Ole Chiewitz and Bliss Bugt boulders and pebbles of a variety of grey and red gneisses and granites and other crystalline rocks were collected from the ground moraine. It is generally accepted that the glacial till of northern Peary Land is formed of locally derived material while that of the southern part of Peary Land, south of an approximate E-W line $33 \mathrm{~km}$ north of Independence Fjord, contains a heterogeneous assemblage which was derived both locally and from distant areas and which contains crystalline granites and gneisses (Davies. 1961). The presence of this boundary between the two types of till, which was first plotted by Koch $(1923,1928)$ and later slightly modified by Troelsen $(1952)$, is interpreted as indicating the maximum northern limit of the Greenland ice cap.

The crystalline erratics collected on the north coast clearly have not been derived from the exposed bedrock of northern Peary Land. Koch (1923, p. 64; 1928, p. 504) 
postulated a nucleus of gneiss and granite in the central part of northern Peary Land and believed that the blocks of granite he found on the north coast of Peary Land were derived from it. This high-grade nucleus, which was disputed by EllitsgaardRasmussen (1955), is now known through field work in the area to be definitely non-existent and the highest grade rocks exposed are garnet-biotite psammites and schists (see Dawes \& Soper, this report). Either the gneiss and granite pebbles and boulders come from the same crystalline region as the granitic and gneissic pebbles recorded in the glacial till of southern Peary Land, in which case they may be a good indication of the northerly extent of part of the ice cap along the coast, or they have been derived from the north. In the latter case they may be either locally derived and an indication of the type of rocks existing on the shelf off the coast of North Greenland or they have been carried long distances across the Arctic Ocean and represent the high-grade rocks of another land mass.

\section{References}

Davies. W. E. 1961 : Glacial geology of northern Greenland. Polarforschung 5. Jahrg. 31. 94-103.

Ellitsgaard-Rasmussen, K. 1955: Features of the geology of the folding range of Peury Land North Greenland. Meddr Gronkand 127. 7.

Koch. L. 1923: Resultaterne af Jubilæumsekspeditionen Nord om Grønland i 1921. Nafurens Verden 7. 49-76.

Koch. L. 1928: The physiography of North Greenland. In Vahl. M. et al. (edit.): Greenland 1. 491-518. Copenhagen: C. A. Reitzel.

Troelsen, J. C. 1952: Notes on the Pleistocene geology of Peary Land, North Greenland. Meddr dansk geol. Foren. 12, 209-220.

\section{LATE PRECAMBRIAN MICROFOSSILS FROM PEARY LAND}

\section{K. Raunsgaard Pedersen}

Examinations of a black chert from the late Precambrium (Eocambrium) of the southern part of Peary Land have revealed several types of microfossils, some of which show affinities to a flora of about the same age from Australia.

During the summer of 1968 the Precambrian and Eocambrian sediments of Jørgen Brønlund Fjord area in southern Peary Land were studied by Jepsen (1969), who brought home the chert sample examined.

The black chert comes from a dolomite series with cherty layers and lenses; it was collected about $100 \mathrm{~m}$ above the upper of the two unconformities (see fig. 2 in Jepsen, 1969). In the upper part of this dolomite series Collenia structures are common (Jepsen, pers. comm.).

The age of the dolomite series is stated as Eocambrium? as it lies between the Lower 